\title{
Powder for Solution for Intraocular Irrigation Dosage Form
}

National Cancer Institute

\section{Source}

National Cancer Institute. Powder for Solution for Intraocular Irrigation Dosage Form. NCl Thesaurus. Code C149850.

Solid sterile preparation consisting of one or more powders intended to be dissolved in the specified liquid to obtain a solution for intraocular irrig ation. 